DOI: $10.21802 / \operatorname{artm} .2021 .1 .17 .27$.

UDC 616.24-007.63- 056.527

\title{
THE IMPLICATION OF SOLUBLE INTERCELLULAR ADHESION MOLECULE IN THE PROGRESSION OF COPD IN OVERWEIGHT PATIENTS
}

\author{
N.V. Korzh, M.M. Ostrovskyy \\ Ivano-Frankivsk national medical university, Department of phthisiology and pulmonology with course of \\ occupational diseases, Ivano-Frankivsk, Ukraine, \\ ORCID ID: 0000-0002-4262-8600,e-mail: nadiyakorzh@gmail.com, \\ ORCID ID: 0000-0002-3922-0583,e-mail:mykola.m.ostrovskyy@gmail.com
}

\begin{abstract}
Due to the high prevalence rates, severity, high risk of disability and death, chronic obstructive pulmonary disease (COPD) still remains an extremely important medical and economic problem not only in Ukraine but also worldwide. According to the WHO estimates, at least 65 million people on our planet suffer from moderate or severe COPD. The severity of the disease and its prognosis are often determined by the influence of concomitant pathology on the frequency of exacerbations, so the problem of comorbidity is becoming increasingly important. Recently, the number of patients with a combination of COPD and overweight is increasing, which is considered as a mutual aggravating factor and negatively affects the prognosis of the disease in such patients. The basis of treatment of patients with COPD is to reduce symptoms, prevent and treat exacerbations, improve exercise tolerance and prevent the progression of the pathology.
\end{abstract}

The objective of the research: to assess the value of SICAM-1 in blood serum as a marker of inflammation and criterion for the treatment of the destabilization phase in COPD III degree of bronchial obstruction in overweight patients.

112 patients with chronic obstructive pulmonary disease (COPD GOLD III) were examined in different phases of pathological process. The main treatment group involved 45 patients suffering from COPD III degree of bronchial obstruction (subgroup I included 18 patients (40\%) with stable phase of pathological process, subgroup II involved 27 patients (60\%) at exacerbation phase), and the experimental group consisted of 67 COPD patients with III degree of bronchial obstruction (subgroup I included 25 patients $(37.3 \%)$ with stable phase of pathological process; subgroup II involved 42 patients $(62.7 \%)$ at exacerbation phase).

The control group involved 23 apparently healthy individuals (AHI). The pulmonary function (PF) test was performed by means of "SPIROKOM" device (Ukraine). The degree of overweight was determined by calculating the body mass index (BMI) using the formula $\mathrm{I}=\mathrm{m} / \mathrm{h}^{2}(\mathrm{~m}$ - body mass in kilograms, $\mathrm{h}$ - height, square of the height in meters $\left(\mathrm{kg} / \mathrm{m}^{2}\right)$. The levels of systemic inflammatory markers were determined by quantitative methods in blood serum: levels of sICAM-1 were identified using ELISA kits (Dialcone, France). While evaluating these indices in the complex therapy of COPD of III degree of bronchial obstruction in patients with overweight, a positive dynamics of its levels was observed on the 10th day. But more significant changes were observed three months after the treatment in those patients who agreed to modify their lifestyle as part of the comprehensive treatment of COPD III degree of bronchial obstruction. According to the research, we found an increase in sICAM-1, more significant in overweight patients, which is one of the manifestations of systemic inflammation in COPD III degree of bronchial obstruction, and complex therapy of this pathology is more effective when modifying the lifestyle of patients.

Keywords: chronic obstructive pulmonary disease, overweight, pulmonary function, sICAM-1.

Introduction. The Global Initiative for Chronic Obstructive Lung Disease (GOLD) guidelines define chronic obstructive pulmonary disease (COPD) as a common disease that can be prevented and treated, and is characterized by persistent respiratory symptoms and airflow limitations that are associated with an abnormal inflammatory response of airways and/or alveoli usually caused by significant exposure to harmful particles or gases [4- 9].

The problem of COPD has been facing global health care system in general and pulmonology in particular for many decades. According to the latest statistics, about $4-22 \%$ of the adult population aged 40 and older suffer from COPD. The prevalence of the disease in the world among men and women is 9.3 and $7.3 \%$, and among smokers -26.2 and $2.7 \%$ respectively $[10,11]$. A number of multicenter researches carried out in developed countries show doubling of morbidity, disability and mortality rates every 10 years. However, every year this nosologic unit retains its sad status of one of the leading causes of death worldwide. According to the data from the World Health Organization, by 2020, COPD is estimated to become the third leading cause of death worldwide. However, in 2016, this disease was placed third ahead of schedule, which has a significant impact on the health care system as a whole (Global Health Estimates 2016: Deaths by cause, age, sex, by country and by region, 2000-2016. Geneva, World Health Organization; 2018).). The range of unresolved issues in this area is not decreasing, and the problem of urgency regarding the timely provision of medical care to such patients still remains, primarily due to the late detection of the disease $[5-7,14,18]$. This is the case of not only our country, but also of other countries, 
including highly developed ones [Feshchenko Yu.I., 2020].

Smoking is known to be one of the main causes of COPD development and amounts for $80-90 \%$ of all cases, though the risk of COPD development is also increased by environmental pollution, genetic and working-environment factors. Currently, the study of the influence of extrapulmonary factors on the development and rapid progression of this pathology is the main direction $[13,15,17]$.

The dominant factor in determining the severity of COPD is the frequency of exacerbations, which show up as acute worsening of respiratory symptoms and are accompanied by increased inflammation in the airways, which lead to severe shortness of breath (the main symptom of exacerbation), increase volumes of the secreted sputum and its increased purulency, as well as exacerbation of cough [adapted clinical guideline, 2020]. These episodes result in limited physical activity, poor quality of life, decreased lung function and are associated with significant mortality rates, especially when rehospitalization is required $[1,12]$. Frequent exacerbations are the most dangerous event in the lives of patients with chronic obstructive pulmonary disease (COPD), because then the risk of death is 4.3 times higher than in patients without exacerbations. According to various researches, the factors influencing the frequency of exacerbations in general are old age, severe airflow obstruction and the history of previous deteriorations and the presence of comorbid pathology, the study of which is currently under consideration. [1-2,17].

According to the scientific literature, the main distinction of COPD is the presence of persistent bronchial obstruction associated with the pathological inflammatory reaction. Systemic inflammation is considered one of the key elements in the pathogenesis of this pathology, which leads to the development of extrapulmonary manifestations. It is this systemic inflammation that connects the course of the inflammatory process in the bronchial tree with the development of systemic manifestations of the disease $[3,12]$. The onset of inflammation is accompanied by the pronounced disorder of microcirculation with the presence of exudation, the development of edema, chemotaxis of leukocytes to the site of inflammation and local proliferation of cellular elements. Local inflammatory process in COPD promotes a systemic inflammatory reaction, which leads not only to the decrease in the functional capacity of the lungs, but also to the formation of systemic manifestations and consequences, including depression, osteoporosis, endothelial dysfunction and cardiovascular disease, muscle loss and skeletal muscle dysfunction $[3,14]$.

Much effort has been made to evaluate the possible role of extrapulmonary factors in increasing the risk of COPD exacerbation. It has been established that comorbid conditions present in COPD patients can aggravate the course of the disease [3, 11,13]. The increasing attention to the comorbid diseases of internal organs at the present stage is due to the fact that comorbidity significantly complicates the process of establishing the disease which dominates in the overall clinical picture at each stage of exacerbation, which entails certain difficulties in the treatment process and planning and carrying out rehabilitation measures. The problem awareness is also associated with the fact that in many cases such course contributes to the progression of one or every disease, the early development of complications, which determines the negative prognosis $[11,15,18]$.

Overweight is one of the leading conditions that can have negative influence on the course of COPD and is recognized as one of the key problems of the $21^{\text {st }}$ century and is one of the non-communicable diseases leading to the increased morbidity and mortality rates, lost productivity and disability, and is a risk factor for the development and rapid progression of a number of chronic diseases, including respiratory tract pathology $[11,12]$. According to the WHO normal body mass index (BMI) is considered to be between $18.5-24.9 \mathrm{~kg} / \mathrm{m}^{2}$, while the BMI of between $25.0-29.9 \mathrm{~kg} / \mathrm{m}^{2}$ is considered as overweight $[7,13]$. The role of overweight in the development and rapid progression of respiratory pathology may be proved by the fact that weight loss leads to the decrease in the degree of clinical manifestations of COPD. It is a proved fact that overweight is accompanied by inflammation of adipose tissue, which occurs with its infiltration by immunocompetent cells. Since the inflammatory reaction occurs in the tissue, which is well vascularized and innervated, the systemic manifestations should be expected [3, 17].

The course, duration and progression of the disease are determined by not only the increase or decrease in the levels, but also by the correlation of pro- and antiinflammatory cytokines, which ensure the sequence and completeness of the immune response, carry out the shortdistant regulation of cell-to-cell cooperation of all parts of the immune system, which affect the magnitude of the immune response to damage in order to develop chronic inflammatory reactions, systemic inflammatory response syndrome (SIRS) [1,2,13]. Cytokines are not only endogenous regulators of the immune response, but also the key factors that induce an inflammatory response and an acute phase response of the body, and may have an immunopathological effect on cells and tissues. In order to carry out an adequate immune response the cells of the immune system must migrate. The implementation of this function is carried out with the participation of cell adhesion molecules (adhesive molecules), which include a soluble intercellular adhesion molecule (sICAM) $[12,16,18]$.

Intercellular adhesion molecules are membranebound proteins. They provide mechanical interaction of cells with each other. With their help, the cells can be "pulled up" to other cells or move in the intercellular space, promoting the following processes: for leukocytes - attachment to the vascular endothelium, extracellular matrix (fibronectin, laminin, collagen); for lymphocytes attachment to each other, the implementation of the homing effect (migration into the T- and B-zones in the peripheral lymphoid organs), attachment to angiopresentative cells; for platelets - attachment to leukocytes and endothelial cells $[12,16]$.

According to the author, the increase in the concentration of antigens of adhesion molecules with increasing severity of the disease may reflect the severity of the inflammatory process, and the content of SISAM-1 in the blood serum may act as the COPD severity indicator 
$[7,12,17]$. Thus, their importance in early and late reactions of the inflammatory response can hardly be exaggerated. At the same time, the role of individual inflammatory markers in the diagnosis, prognosis of progression and improvement of management approach and treatment of patients with COPD in the modern scientific literature is not sufficiently outlined $[10,18]$.

The objective of the research: to assess the value of sICAM-1 in blood serum as a marker of inflammation and criterion for the treatment of the destabilization phase in COPD III degree of bronchial obstruction in overweight patients.

Material and methods: The verification of the diagnosis of COPD and its formulation was carried out in accordance with the Order of the Ministry of Health of Ukraine №555 from June 27, 2013 “On approval and implementation of medical-technological documents on standardization of medical care in chronic obstructive pulmonary disease". Patients who are in a stable phase of the process received baseline therapy in accordance with the currently valid order of the Ministry of Health of Ukraine №555 from June 27, 2013, which involved the use of longacting bronchodilators, inhalational and systemic glucocorticosteroids, and, if necessary, short-acting bronchodilators.

Complex therapy of patients with exacerbation of COPD with III degree of bronchoconstriction was carried out according to the schedules covered in the order of the Ministry of Health of Ukraine №555 from June 27, 2013. It was aimed at the elimination of inflammatory process in bronchi (glucocorticosteroid nebulations, administration of high-doses of inhalational glucocorticosteroids with preference to their combinations with prolonged action beta-2-agonists (fluticasone + salmeterol, budesonide + formoterol), and systemic glucocorticosteroids if necessary); restoration of adequate ventilation (inhalational short-acting and long-acting $\beta 2$ agonists: salbutamol sulfate, fenoterol hydrobromide, salmeterol, formoterol fumarate, with preference given to nebulization with the combination of short-acting $\beta 2$ agonists and cholinolytics (ipratropium bromide + fenoterol hydrobromide), if treatment with inhalational bronchodilators failed, prolonged oral administration of theophylline or intravenous euphylline by drop infusion were used); restoration of mucociliary clearance (ambroxol, acetylcysteine), elimination of the etiological factor of exacerbation.

In case of infectious exacerbation of COPD (III degree of bronchoconstriction), the initial antibacterial therapy was of an empirical character, predominantly involving the administration of oral antibacterial drugs: aminopenicillins, inhibitor-protected aminopenicillins or macrolides, if necessary (ineffectiveness of therapy, allergic reactions) - respiratory fluoroquinolones were used. Sequential antibacterial therapy was used in $75 \%$ of cases and it involved the transition from parenteral administration of medications to enteral route of administration. The criteria for enteral route of antibiotic administration included: patient's normal body temperature taken twice within 8 hours; reduced dyspnea or its total absence; absence of alterations of consciousness and patient's desire to take medications orally. Patients were also prescribed specific breathing exercises, inhalations of broncholytic, expectorative and antiseptic phytopreparations; appropriate diet and regimen.

The main treatment group involved 45 patients suffering from COPD III degree of bronchial obstruction (male patients - 37 (75.6\%), female patients - $11(24.4 \%)$ with obesity); the average age was $(61.9 \pm 3.1)$ years. They were divided into subgroups depending on the phase of their pathology: subgroup I included 18 patients $(40 \%)$ with stable phase of pathological process, subgroup II involved 27 patients $(60 \%)$ at exacerbation phase.

The experimental group consisted of 67 COPD patients with III degree of bronchial obstruction (male patients - 51 (76.1\%), female patients 17 (25.4\%) with normal body weight; average age $-(62.9 \pm 2.8)$ years. They were also divided into subgroups depending on the phase of their pathology: subgroup I included 25 patients $(37.3 \%)$ with stable phase of pathological process; subgroup II involved 42 patients $(62.7 \%)$ at exacerbation phase.

The control group involved 23 apparently healthy individuals (AHI) representative by sex and age, without any signs of pulmonary diseases or other pathologies of internal organs, 12 of which were overweight.

The investigation was performed in the phase of remission and at the time of verification of the development of exacerbation phase. All the surveyed patients gave their consent to participate in clinical trial.

The average duration of the disease in patients with COPD III degree of bronchial obstruction was (26.8 \pm 1.4$)$ years in those with obesity, and (31.4 \pm 1.2$)$ years in patients with normal body weight. Among the existing risk factors, which triggered the COPD development in both main treatment group and comparison group, tobacco smoking was prevalent: 29 individuals $(64.4 \%)$ with average smoking history of (17.8 $\pm 2.1)$ pack-years and 48 individuals (71.64\%) with average smoking history of $(19.9 \pm 2.2)$ pack-years.

Computed spirometry with the help of "SpiroCom medic" (KhAI, Kharkiv, Ukraine) was used to study the indices of respiratory function with indicators of main bronchoobstructive indices (forced vital capacity (FVC) of lungs, forced expiratory volume (FEV1)).

The levels of systemic inflammatory markers were determined by quantitative methods in blood serum: levels of sICAM-1 were identified using ELISA kits (Dialcone, France).

Statistical processing of research materials was carried out using biometric analysing methods implemented in software packages EXCEL-2003 (№ 74017641-9475201-57075) and STATISTICA 6.0 (№ 31415926535897). The assessment of statistical significance of mean values for independent samples was performed by means of Student's and Mann-Whitney tests, while dispersion was evaluated with Fisher's test. The difference between the comparative values was considered to be significant at $\mathrm{p}<0.05$, while the tendency of changes was indicated in the range of $0.05<\mathrm{p}<0.10$, with the index rate calculated to the thousandths place.

Research findings and their discussion. The obtained findings showed that the increase in SICAM-1 levels was a characteristic feature for the course of COPD III degree of bronchial obstruction. Thus, we observed an increase of sICAM-1 levels in blood serum in the phase of 
remission in COPD patients with III degree of bronchial obstruction and normal body weight, as compared to the group of apparently healthy individuals (AHI), namely by 1.2 times $(\mathrm{p} 3<0.05)$. In the exacerbation phase this index was 1.1 times higher $(\mathrm{p} 6<0.05)$ than the same indices registered in the comparison group in the remission phase and 1.3 times higher $(\mathrm{p} 4<0,001)$ than the same indices in patients from the group of AHI, respectively. However, more significant increase of this markers was observed in overweight patients, especially in the phase of destabilization of the clinical course of the disease. Thus, we have observed an increase in blood serum sICAM-1 levels in the exacerbation phase as compared with the remission phase, namely by 1.3 times ( $\mathrm{p} 5<0.01)$, and 1.5 times $(\mathrm{p} 2<0.005)$ in comparison with the same index recorded in patients of the AHI group. In the exacerbation phase, these indices were 1.2 times higher $(\mathrm{p} 1<0.05)$ than the same indices recorded in the comparison group (Table 1).

Table 1

The level of sICAM-1 in the examined COPD patients with III degree of bronchial obstruction in relation to the body weight, $(M \pm m)$

\begin{tabular}{|c|c|c|c|c|c|c|c|c|c|c|c|c|c|c|}
\hline \multirow[b]{2}{*}{ Index } & \multirow[b]{2}{*}{ 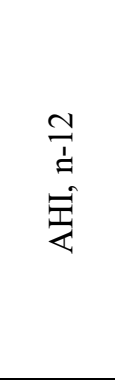 } & \multicolumn{2}{|c|}{$\begin{array}{l}\text { Main treatment } \\
\text { group } n=45\end{array}$} & \multirow[b]{2}{*}{ 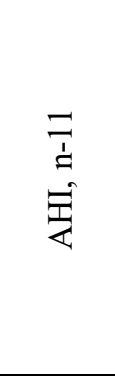 } & \multicolumn{2}{|c|}{$\begin{array}{c}\text { Comparison group } \\
n=67\end{array}$} & \multirow[b]{2}{*}{$\overline{2}$} & \multirow[b]{2}{*}{$\stackrel{2}{2}$} & \multirow[b]{2}{*}{2} & \multirow[b]{2}{*}{2} & \multirow[b]{2}{*}{$\stackrel{2}{2}$} & \multirow[b]{2}{*}{2} & \multirow[b]{2}{*}{$\hat{2}$} & \multirow[b]{2}{*}{$\stackrel{\infty}{2}$} \\
\hline & & 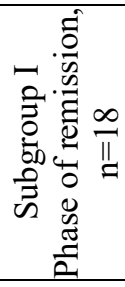 & 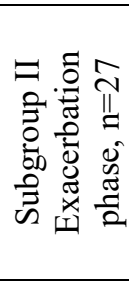 & & 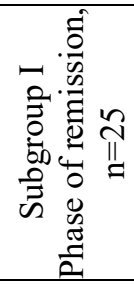 & 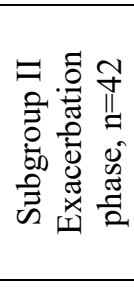 & & & & & & & & \\
\hline $\begin{array}{c}\text { Sicam } \\
-1, \\
\mathrm{ng} / \mathrm{ml}\end{array}$ & $\begin{array}{c}443,20 \\
\pm \\
21,40\end{array}$ & $\begin{array}{c}514,00 \\
\pm \\
24,30\end{array}$ & $\begin{array}{c}658,20 \\
\pm \\
34,30\end{array}$ & $\begin{array}{c}401,60 \\
\pm \\
22,0\end{array}$ & $\begin{array}{c}485,20 \\
\pm \\
22,20\end{array}$ & $\begin{array}{c}527,20 \\
\pm \\
26,20\end{array}$ & $\stackrel{n}{6}$ & $\stackrel{\bar{\delta}}{\hat{v}}$ & $\begin{array}{l}\overrightarrow{0} \\
\dot{v}\end{array}$ & $\begin{array}{l}\bar{\delta} \\
\hat{\sigma}\end{array}$ & $\begin{array}{l}\bar{\sigma} \\
\hat{v}\end{array}$ & $\begin{array}{l}n \\
\hat{n}\end{array}$ & $\stackrel{n}{0}$ & $\begin{array}{l}\bar{\delta} \\
\dot{v}\end{array}$ \\
\hline
\end{tabular}

Note: p1 - significant difference between the main group in the remission phase and the group of AHI with overweight; p2- significant difference between the main group at exacerbation phase and the group of AHI with overweight; p3significant difference between the comparison group in the remission phase and the group of AHI with normal body weight ; p4- significant difference between the comparison group at exacerbation phase and the group of AHI with normal body weight; p5- significant difference between the main group in the remission phase and the main group at exacerbation phase; p6- significant difference between the comparison group in the remission phase and the comparison group at exacerbation phase; p7- significant difference between the main group in the remission phase and the comparison group in the remission phase; p8- significant difference between the main group at exacerbation phase and the comparison group at exacerbation phase and the comparison group at exacerbation phase.

While evaluating these indices in comprehensive therapy of COPD III degree of bronchial obstruction in overweight patients, we have noticed some positive dynamics. Thus, on day 10 from the start of treatment, the level of sICAM-1 has decreased by 1.2 times $(\mathrm{p}<0.05)$, and made up $548.5 \pm 5.3 \mathrm{ng} / \mathrm{ml}$, as compared to $658.2 \pm 6.1$.
However, more significant changes were observed three months after the treatment in those patients who agreed to modify their lifestyle as part of the comprehensive treatment of COPD III degree of bronchial obstruction. This index in such patients was 470.1 \pm 5.1 $\mathrm{ng} / \mathrm{ml}$, which is 1.4 times $(\mathrm{p}<0.05)$ lower than the data obtained before the treatment (Table 2).

Table 2

Levels of SICAM-1 recorded on the 15-16 ${ }^{\text {th }}$ day and 3 months after the treatment of the exacerbation phase of chronic obstructive pulmonary disease III degree of bronchoobstruction in patients with overweight (M $\pm \mathbf{m})$

\begin{tabular}{|c|c|c|c|c|c|c|}
\hline \multirow{2}{*}{ Index } & \multicolumn{2}{|c|}{ COPD III degree of bronchoobstruction in patients with overweight, $\mathrm{n}=45$} & \\
\cline { 2 - 7 } & AHI, n-12 & Before treatment & $10^{\text {th }}$ day of treatment & 3 months after the treatment & $\vec{\Omega}$ & \multirow{2}{*}{} \\
\hline sICAM-1 ng/ml & $443.2 \pm 3.1$ & $658.20 \pm 6.10$ & $548.50 \pm 5.31$ & $470.14 \pm 9.82$ & $\overline{8}$ & $\overline{8}$ \\
\hline
\end{tabular}

Note: $\mathrm{p} 1$ - the reliability of the difference at the beginning and on the 10th day of treatment; $\mathrm{p} 2$ - the reliability of the difference at the beginning and after 3 months of treatment; 


\section{Conclusions:}

1. It has been established that COPD III degree of bronchoobstruction is accompanied by severe manifestations of systemic inflammations in the body, which show up as the increase in the sICAM-1level. However, this pathology in combination with excessive body weight is characterized by more pronounced changes, which is confirmed by the data we obtained while studying these indices.

2. The use of comprehensive treatment with administration of xanthine and lifestyle modifications in the treatment of chronic obstructive pulmonary disease III degree of bronchial obstruction in overweight patients has more positive effect on the inflammatory activity, that became obvious with the significant decrease in sICAM-1 levels and improved clinical symptoms.

\section{References:}

1. Hashynova KYu. Zahostrennia KHOZL: informatyvnist kliniko-anamnestychnykh ta laboratorno-instrumentalnykh pokaznykiv $\mathrm{u}$ prohnozuvanni ymovirnosti povtornoi hospitalizatsii. (Exacerbation of COPD: informative clinical-anamnestic and laboratory-instrumental indices in predicting the likelihood of re-hospitalization). Ukr.Pulmonol.Zhurnal. 2015; 2:60-64.

2. Hriadil TI, Chubirko KI, Chopei IV, Hechko MM, et al. Diahnostyka, likuvannia ta profilaktyka ozhyrinnia (Diagnosis, treatment and prevention of obesity). Ukraina. Zdorovia Natsii. 2015; 1(33):96-100.

3. Dihtiar NI, Herasymenko ND, SavchenkoLV, et al. Systemne zapalennia nyzkoi intensyvnosti yak zahalna osnova khronichnoho obstruktyvnoho zakhvoriuvannia lehen ta komorbidnykh staniv (Lowgrade systemic inflammation as the common ground for chronic obstructive pulmonary disease and comorbid conditions). Ukr.Pulmonol.Zhurnal. 2016; 3:64-68.64.

4. Konopkina LI, Pertseva TO. Suchasni pohliady na diahnostyku ta likuvannia khronichnoho obstruktyvnoho zakhvoriuvannia lehen (Modern views on the diagnosis and treatment of chronic obstructive pulmonary disease). Ukr.Pulmonol.Zhurnal. 2018; 3(annex):16-18.

5. Korzh NV, Ostrovskyy MM. Markery systemnoho zapalennia ta nadmirna masa tila $u$ khvorykh na khronichne obstruktyvne zakhvoriuvannia lehen iz III stupenem bronkhoobstrukcii (Systemic inflammatory markers and overweight in patients suffering from chronic obstructive pulmonary disease with III degree of bronchial obstruction). Astma ta alergiia. 2019; 2:10-16.

6. Korzh NV, Ostrovskyy MM. KhOZL ta nadmirna vaha, yak problema suchasnoj pulmonolohii (COPD and overweight as a problem of modern pulmonology). Halytskyi Likarskyi Visnyk. 2018; 25-1:48-51.

7. Krakhmalova OO, Shtorkh VV, Hetman OA, et al. Khronichne obstruktyvne zakhvoriuvannia lehen i suputni patolohichni stany. Osoblyvosti porushen rytmu sertsia (Chronic obstructive pulmonary disease and associated pathological conditions. Characteristics of heart rhythm disorders). Ukr.Ter.Zhurnal. 2016; 2:119-123.
8. Mostovyi YuM. Khronichne obstruktyvne zakhvoriuvannia lehen. Kliuchovi pytannia (Chronic obstructive pulmonary disease. Key issues). Ukr.Med.Chasopys. 2016; 4:63-66.

9. Mostovoi YuM, Pertseva TO, Ostrovsky MM. Obstruktyvni zakhvoriuvannia lehen: realii klinichnoi praktyky (Obstructive pulmonary disease: the realities of clinical practice). Zdorovia Ukrainy. 2017; 2:5-7.

10. Order of the Ministry of Health of Ukraine №555 from June 27, 2013 "Pro zatverdzhennia ta vprovadzhennia medyko-tekhnolohichnykh dokumentiv zi standartyzatsii medychnoi dopomohy pry khronichnomu obstruktyvnomu zakhvoriuvanni lehen (On approval and implementation of medical-technological documents on standardization of medical care in chronic obstructive pulmonary disease)". URL: http://www.moz.gov.ua/ua/portal/dn_20131 008 0868.html.

11. Mostovoi YuM, Rasputina LV, Dovhan AO, Ovcharuk MV. Problema komorbidnykh staniv u Natsionalnii uhodi z diahnostyky ta likuvannia khronichnoho obstruktyvnoho zakhvoriuvannia lehen iz pozytsii vlasnoho dosvidu. Obhovorennia Nakazu №555. (The problem of comorbid conditions in the National agreement on the diagnosis and treatment of chronic obstructive pulmonary disease from the standpoint of own experience. Discussion of the Order №555). Bukovynskyi Medychnyi Visnyk. 2014; 18(3):221-226.

12. Dihtiar NI, Herasymenko ND, SavchenkoLV, et al. Systemne zapalennia nyzkoi intensyvnosti yak zahalna osnova khronichnoho obstruktyvnoho zakhvoriuvannia lehen ta komorbidnykh staniv (Low-grade systemic inflammation as the common ground for chronic obstructive pulmonary disease and comorbid conditions). Ukr.Pulmonol.Zhurnal. 2016; 3:64-68.64.

13. Treumova SI, Petrov YeYe, Boriak VP. Khronichne obstruktyvne zakhvoriuvannia lehen $\mathrm{u}$ poiednanni $\mathrm{z}$ metabolichnym syndromom (Chronic obstructive pulmonary disease combined with metabolic syndrome). Visnyk Problem Biolohii i Medytsyny. 2015; 1:33-36.

14. Feshchenko YuI. KhOZL v Ukraine: problemy i puti resheniia (COPD in Ukraine: problems and solution). [Electronic resource] Zdoroviia Ukrainy. 2015; March, 27.

15. Feshchenko YuI, Chaikovskyi YuB, Ostrovskyi MM, et al. Khronichne obstruktyvne zakhvoriuvannia lehen. Novi vidtinky problemy (Chronic obstructive pulmonary disease. New shades of the problem). IvanoFrankivsk. 2016. P.400.

16. Rabe KF, Lichtinghagen R, et. al. Angiopoietin-like protein 4 and cardiovascular functionin COPD. BMJ Open Respiratory Research. 2016; 3(1).

17. Barnes PJ. Inflammatory mechanisms in patients with chronic obstructive pulmonary disease. J. Allergy Clin. Immunol. 2016; 138(1):16-27.

18. Global initiative for chronic obstructive lung diseases (GOLD). Global strategy for diagnosis, management and prevention of chronic obstructive lung diseases. NHLB/WHO workshop report. URL: http: // www. goldcopd.com 


\section{УДК 616.24-007.63- 056.527 \\ РОЛЬ РОЗЧИННОӤ МОЛЕКУЛИ \\ МІЖКЛІТИННОЇ АДГЕЗІЇ У ПРОГРЕСУВАННІ ХОЗЛ У ХВОРИХ 3 НАДМІРНОЮ МАСОЮ ТІЛА}

Н.В. Корж, М.М. Островський

Івано-Франківський начіональний медичний університет, кафедра фтизіатрії та пульмонології з курсом професійних хвороб, м. Івано-Франківськ, Украӥна, ORCID ID: 0000-0002-4262-8600,

e-mail: nadiyakorzh@gmail.com, ORCID ID: 0000-0002-3922-0583,

e-mail: mykola.m.ostrovskyy@gmail.com

Резюме. Через значну поширеність, тяжкість перебігу, високий ризик інвалідності та смерті хронічне обструктивне захворювання легень (ХОЗЛ) продовжує залишатись надзвичайно вагомою медичною та економічною проблемою не тільки в Україні, а й в усьому світі. За оцінками ВОО3, не менш ніж 65 мільйонів мешканців нашої планети страждають на помірний або тяжкий перебіг ХОЗЛ. Тяжкість перебігу захворювання та його прогноз часто визначаються впливом супутньої патології на частоту загострень, тому проблема коморбідності набирає все більшої актуальності.

Мета дослідження. Оцінити значення вмісту sICAM-1 в сироватці крові в якості маркеру запалення та критерію лікування фази дестабілізації при ХОЗЛ III ступеня бронхообструкції у хворих з надмірною масою тіла. Обстежено 112 пацієнтів із хронічною обструктивною хворобою легень у різні фази патологічного процесу. Дослідження функції зовнішнього дихання проводилось за допомогою апарату "SPIROKOM" (Україна). Ступінь зайвої ваги визначали шляхом обчислення індексу маси тіла (IMT) за формулою $\mathrm{I}=\mathrm{m} / \mathrm{h}^{2}$. Рівні маркерів системного запалення визначалися кількісними методами у сироватці крові: sICAM-1 за допомогою ELISA-набору (Dialcone, Франція). Оцінка даного показника при комплексній терапії ХОЗЛ III ступеня бронхообструкції у хворих 3 надмірною масою тіла показала позитивну динаміку його рівнів уже на 10-й день. Більш показовими були зміни при контролі через 3 місяці у хворих, які дали згоду на застосування модифікації способу життя у комплексній терапії ХОЗЛ ІІІ ступеня бронхообструкції. За допомогою даних досліджень нами встановлено зростання рівня SICAM-1 більш показово у пацієнтів з надмірною масою тіла, що є одним із проявів системного запалення в організмі при ХОЗЛ ІІІ ступеня бронхообструкції, а комплексна терапія даної патології є більш ефективна при застосуванні модифікації способу життя пацієнтів.

Ключові слова: хронічне обструктивне захворювання легень, надмірна маса тіла, функція зовнішнього дихання, sICAM-1.

\section{УДК 616.24-007.63- 056.527 \\ РОЛЬ РАСТВОРИМОЙ МОЛЕКУЛЫ МЕЖКЛЕТОЧНОЙ АДГЕЗИИ В ПРОГРЕССИРОВАНИИ ХОБЛ У БОЛЬНЫХ С ИЗБЫТОЧНОЙ МАССОЙ ТЕЛА}

\section{Н.В. Корж, Н.Н. Островский}

Ивано-Франковский нацииональный медиичнский университет, кафедра фтизиатрии и пульмонологии с курсом профессиональных болезней,

Ивано-Франковск, Украина,

ORCID ID: 0000-0002-4262-8600,

e-mail: nadiyakorzh@gmail.com,

ORCID ID: 0000-0002-3922-0583,

e-mail: mykola.m.ostrovskyy@gmail.com

Резюме. Из-за значительной распространенности, тяжести течения, високого риска инвалидности и смерти хроническое обструктивное заболевание легких (ХОЗЛ) остается чрезвычайно важной медицинской и экономической проблемой не только в Украине, но и во всем мире. По оценкам ВОО3, не менее 65 милионов жителей нашей планеты страдают умеренным или тяжелым течением ХОБЛ. Тяжесть течения заболевания и его прогноз часто определяются влиянием сопутствующей патологии на частоту обострений, поэтому проблема коморбидности обретает все большую актуальность.

Цель исследования. Оценить значение уровня SICAM-1 в сыворотке крови в качестве маркера воспаления и критерия лечения фазы дестабилизации при ХОБЛ III степени бронхообструкции у больных с избыточной массой тела. Обследовано 112 пациентов с хронической обструктивной болезнью легких в различные фазы патологического процесса. Исследование функции внешнего дыхания проводилось с помощью аппарата "SPIROKOM" (Украина). Степень лишнего веса определяли вычислением индекса массы тела (ИМТ) по формуле $\mathrm{I}=\mathrm{m} / \mathrm{h}^{2}$. Уровни маркеров системного воспаления определялись количественными методами в сыворотке крови: sICAM-1 с помощью ELISA набора (Dialcone, Франция). При оценке данного показателя при комплексной терапии ХОБЛ III степени бронхообструкции у больных с избыточной массой тела наблюдалась положительная динамика его уровней уже на 10-й день. Более показательными были изменения при контроле через 3 месяца у тех больных, которые дали согласие на применение модификации образа жизни в комплексной терапии ХОБЛ ІІІ степени бронхообструкции.

При помощи данного исследования нами установлено повышение уровня sICAM-1 более показательно у пациентов с избыточной массой тела, что является одним из проявлений системного воспаления в организме при ХОБЛ III степени бронхообструкции, а комплексная терапия данной патологии является более эффективной при применении модификации образа жизни пациентов.

Ключевые слова: хроническое обструктивное заболевание легких, избыточная масса тела, функция внешнего дыхания, sICAM-1.

Стаття надійшла в редакцію 20.01.2021 p. 